\title{
Relationship of food intake to the induction of plasma sex steroid-binding protein and testicular activity in immature male little brown bats (Myotis lucifugus lucifugus)
}

\author{
D. A. Damassa and A. W. Gustafson \\ Department of Anatomy and Cellular Biology, Tufts University Schools of Medicine, \\ Dental Medicine and Veterinary Medicine, 136 Harrison Avenue, Boston, Massachusetts 02111, \\ U.S.A.
}

\begin{abstract}
Summary. Immature male little brown bats were aroused prematurely from their first hibernation and fed ad libitum (Group AL) or given a restricted diet (Group FR). All animals were weighed daily and the food intake of Group FR males was restricted to maintain their body weights at or near initial post-arousal values $(5 \cdot 3-6.8 \mathrm{~g})$. The average body weights of Group $\mathrm{AL}$ males increased during the first week after arousal and then stabilized at a level which was $20 \%$ higher than those of Group FR males. The post-arousal induction of plasma SBP was similar in Groups FR and AL: plasma SBP activity was significantly increased 1 week after arousal and by 3 weeks had reached levels which were more than 10-fold higher than those of immature hibernating males which served as controls. Although food restriction had no effect on plasma SBP levels, it did inhibit reproductive development. Arousal-induced increases in testicular and epididymal (head/body) weights in Group FR males were $<50 \%$ of those in Group AL males. However, histological examination of the testes revealed similar degrees of spermatogenic activation in both groups. Plasma testosterone concentrations were increased markedly in Groups FR and AL; values were generally lower in Group. FR but wide individual variations were observed. Despite these elevated peripheral testosterone values, the accessory sex glands in both groups remained unstimulated.
\end{abstract}

\section{Introduction}

Sex steroid-binding protein (SBP) is a $\beta$-globulin of liver origin, which has been identified in the plasma of many mammalian species and exhibits high affinity for the androgens $5 \alpha$ dihydrotestosterone and testosterone (for reviews see, Anderson, 1974; Heyns, 1977; Bardin et al., 1981 ; Pardridge, 1981 ; Ekins, 1982; Siiteri et al., 1982; Pétra et al., 1983). In men, circulating concentrations of this protein are low during late fetal life, then rise dramatically within weeks after birth, and remain elevated until the onset of puberty (for reviews, see Anderson, 1974; Heyns, 1977). Although a perinatal rise in plasma SBP concentrations has also been described for male monkeys (Anderson et al., 1976), rabbits (Berger et al., 1980), hamsters (Gustafson, Damassa \& Kwiecinski, 1984) and bats (Gustafson \& Damassa, 1984), the factor(s) which induces the rise as well as the effects of elevated SBP concentrations on male reproductive function are poorly understood.

Amongst those species in which a perinatal rise in plasma SBP has been described, the male little brown bat is particularly useful for studies on the control and action of SBP. In this species, the pubertal process occurs in two distinct phases, which are separated by a winter hibernation period. Just before the onset of this first hibernation, plasma SBP concentrations return to low prenatal 
values and remain at basal levels throughout the winter. After emergence from hibernation in the spring, these bats undergo a reinitiation of the pubertal process: plasma SBP titres rise in a postnatal-like manner, testis weight increases and the spermatogenic cycle leading to sexual maturity commences (Gustafson \& Damassa, 1984). If immature male little brown bats are collected during the second half of their first hibernation and housed in the laboratory under controlled conditions, these perinatal-like increases in SBP levels as well as the precocious onset of spermatogenesis can be induced experimentally (Damassa, Gustafson \& Chari, 1983; Damassa \& Gustafson, 1984). In previous studies we have found that this induction of SBP in immature males is independent of gonadal activity and does not appear to be affected by changes in photoperiod (Damassa \& Gustafson, 1984).

The increases in plasma SBP activity observed in immature bats during the perinatal period or during the period after arousal from hibernation occur during times of profound dietary changes. In that (1) SBP in mammals is presumed to be produced by the liver, (2) the major venous drainage of the gastrointestinal tract occurs via the hepatic portal system, and (3) food availability and type have marked effects on reproductive function in domestic and feral mammals (for reviews, see Leathem, 1970, 1975; see also 'Discussion'), changes in food intake and/or diet could alter the production of SBP in bats and thereby influence reproductive development during the pubertal period.

Therefore, the following study was conducted to determine whether increases in food intake and body weight after arousal from hibernation could be a factor which influences the induction of SBP activity in immature male little brown bats. In addition, the effects of food availability on the resumption of the pubertal process in this species were also examined.

\section{Materials and Methods}

Animals and housing conditions. Immature male little brown bats (Myotis lucifugus lucifugus) were collected in April at natural hibernacula in central New England. Animals were transported to the laboratory in torpor $\left(4^{\circ} \mathrm{C}\right)$ and within $24 \mathrm{~h}$ of collection were aroused, weighed, trained to feed, and housed in an environmental chamber. This chamber was maintained at $25 \pm 1^{\circ} \mathrm{C}$ with a photoperiod of $16 \mathrm{~h}$ light per $24 \mathrm{~h}(16 \mathrm{~L}: 8 \mathrm{D}$; lights on at $03: 00 \mathrm{~h})$. Animals were housed singly in cage modules which were constructed from rigid plastic mesh $(1.3 \mathrm{~cm}$ squares) and attached so that body contact between adjacent bats was possible through the mesh. Access to food, which consisted of high protein-fed mealworms (larvae of the beetle Tenebrio molitor), was restricted for one group of animals as described below; water was available ad libitum to all animals.

Plasma SBP and testosterone measurements. Plasma concentrations of SBP were determined using the DEAE-cellulose filter assay of Mickelson \& Pétra (1974) as previously described (Damassa et al., 1983). The sensitivity of this assay was $12 \mathrm{fmol} /$ tube. Plasma testosterone was determined using a highly specific radioimmunoassay as previously described and validated for use in Myotis (Gustafson \& Damassa, 1984). The sensitivity of this assay (2 s.d. from zero dose) was 8 $\mathrm{pg} /$ tube. Recoveries were consistently $>95 \%$ and no corrections were applied. Water blanks were below the sensitivity of the assay. All samples were assayed in duplicate. Inter-assay coefficients of variation, determined from measurements of plasma pools which were assayed in each of 10 consecutive assays, were $11 \%$ for the SBP assay and $4 \%$ for the testosterone assay.

Experimental procedure. After arousal from hibernation, 18 immature male bats were randomly assigned to the food-restricted (FR) group or the ad libitum-fed (AL) group. In addition, a third group of 6 immature males served as hibernation controls (HC). At the time of arousal, bats in Group HC were anaesthetized, exsanguinated, and their reproductive tissues collected for histological analysis (see below). Animals in Groups FR and AL were weighed daily and the food supply of Group FR males was adjusted to maintain the body weight for each animal at or near its 
initial, post-arousal weight $(5 \cdot 3-6 \cdot 8 \mathrm{~g})$. All blood samples were obtained from ether-anaesthetized animals between $08: 00$ and 12:00 h. Blood samples were obtained from the bats in Groups FR and AL $24 \mathrm{~h}$ after arousal and again at weekly intervals thereafter. Repeated samples $(25 \mu \mathrm{l} \mathrm{each})$ were collected from the wing vein using bevelled, calibrated microcapillary tubes as previously described (Gustafson \& Damassa, 1985). After 3 weeks, a terminal blood sample was collected and reproductive organs were dissected free of extraneous connective tissues and weighed. Immediately after weighing, the testes, epididymides, and the sex accessory gland complex of each bat were immersed in Duboscq-Brasil fixative, subsequently embedded in Paraplast Plus (Lancer, Sherwood Medical, St Louis, MO), sectioned, and stained for histological analysis. Blood samples were placed on ice immediately after collection, centrifuged and the plasma stored at $-20^{\circ} \mathrm{C}$ until assay for SBP and testosterone.

Statistical analyses. Data for various groups are reported as mean \pm s.e.m. Differences between groups were assessed using Student's $t$ test ( 2 independent groups or limited number of a-priori comparisons) or by a Student-Newman-Keuls (SNK) multiple-comparison test, if warranted, following analysis of variance (ANOVA). Daily body weight determinations for each animal were averaged on a weekly basis and statistical analysis performed on the weekly averages. Endocrine measurements were subjected to logarithmic transformation before statistical analysis. A $P$ value of $\leqslant 0.05$ was regarded as significant.

\section{Results}

The mean body weight data for the bats in Groups FR and AL are shown in Text-fig. 1. Body weights at the time of arousal from hibernation were comparable in the two groups. Although some variation was seen in Group FR over the course of the experiment, body weights for all animals in this group were maintained within the range of weights of animals at the time of arousal $(5 \cdot 3-6 \cdot 8 \mathrm{~g})$.

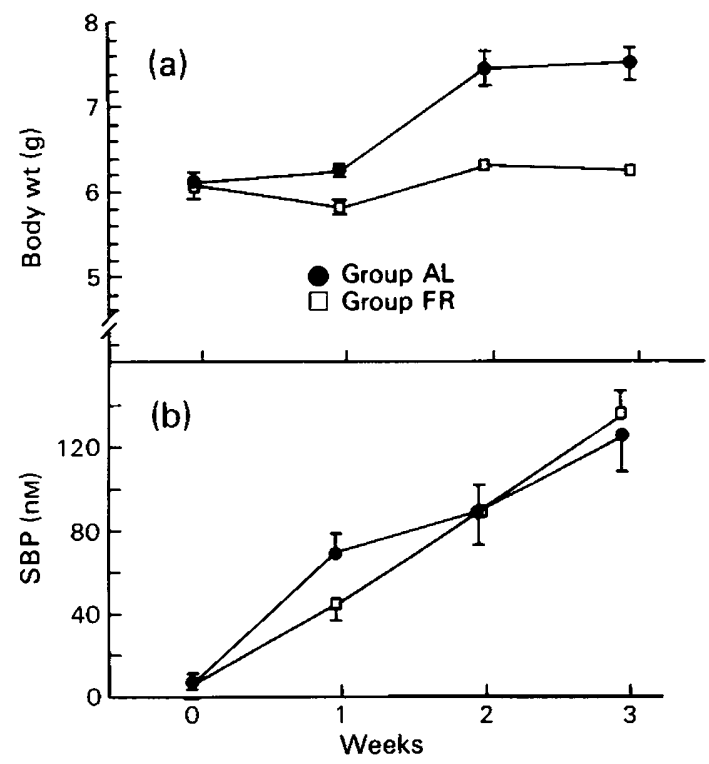

Text-fig. 1. Body weights (a) of and plasma SBP concentrations (b) in immature male little brown bats maintained on a restricted diet (Group FR) or ad libitum-fed (Group AL) after arousal from hibernation. Animals were aroused from hibernation 1 month prematurely and housed in the laboratory under a long photoperiod $(16 \mathrm{~L}: 8 \mathrm{D})$ at $25^{\circ} \mathrm{C}$. Values are mean \pm s.e.m. for 9 animals per group. Error bars not shown are contained within the symbols. 
Bats in Group AL showed a slight increase in body weight during the first week and an even greater, and significant increase, during the second week of the experiment (one-way ANOVA, SNK tests). Mean body weights of the animals in Group AL were significantly higher than those in Group FR throughout the experiment (1,2 and 3 weeks; $t$ tests).

Plasma SBP titres for the animals in Groups FR and AL are shown in Text-fig. 1. Two-way ANOVA revealed that there were no differences in plasma SBP concentrations between the 2 groups $(P=0.6)$ but that there was a significant increase in plasma SBP titres over time in both groups $(P<0.001)$. Food restriction therefore had no effect on the induced rise of plasma SBP which followed premature arousal from hibernation. At the end of the experiment, 3 weeks after arousal, plasma SBP titres in bats in Groups FR and AL were more than 10-fold higher than those of bats in Group HC (HC: $12 \pm 3 \mathrm{nM}$; FR: $137 \pm 11 \mathrm{nM}$; AL: $126 \pm 17 \mathrm{nM})$.

Testicular weights (Text-fig. 2) increased markedly in Groups FR and AL when compared to those of the hibernating control males (one-way ANOVA, SNK tests). In addition, testicular weights in Group AL were significantly greater than those measured in Group FR (SNK test; see Text-fig. 2). This difference in testicular weights was significant when expressed either on an absolute basis or relative to body weight. Even though the testicular weights were lower in Group FR when compared to Group $\mathrm{AL}$, histological analysis of the testis failed to reveal major differences between the two groups. In both, spermatogenesis had proceeded to meiotic prophase and the Leydig cells appeared activated (hypertrophic).

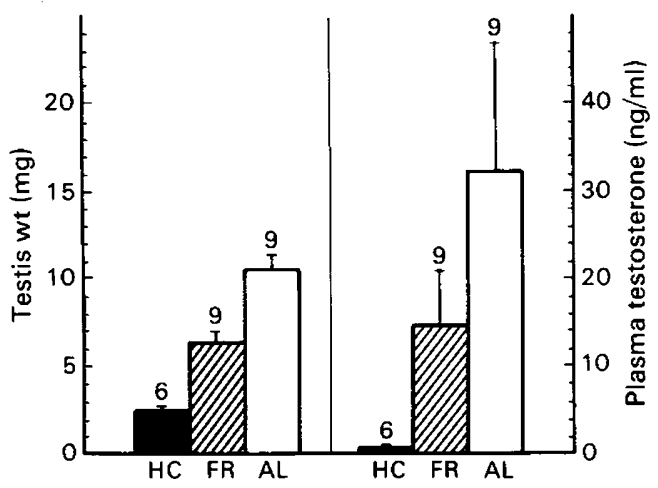

Text-fig. 2. Testis weight and total plasma testosterone concentrations in immature male bats. Animals were aroused prematurely from hibernation and fed a restricted diet (FR) or provided food ad libitum (AL) for 3 weeks. Animals examined at the time of arousal served as hibernation controls $(\mathrm{HC})$. Values are mean \pm s.e.m. for the number of animals indicated.

Plasma testosterone concentrations were significantly higher in males in Groups FR and AL than in those in Group HC (SNK tests). Although testosterone values in Group FR were lower than those in Group AL on a mean basis, individual variations were wide and an SNK test revealed that there were no significant differences between the two groups. However, the differences between these two groups as assesed by a $t$ test were significant.

The epididymis also tended to show increases in total weight in Groups FR and AL when compared to Group HC (Table 1). Regional analysis of this organ, however, revealed that these increases were apparently due to increases in weights of the head/body region. This area was also the only portion of the epididymis which showed some histological evidence of stimulation. In addition, as was observed for testicular weights, the weights of the head/body region were significantly greater in Group AL males than in Group FR males (see Table 1).

The accessory sex glands like the tail region of the epididymis, remained unstimulated histologically in Groups FR and AL (see Table 1), and their weights were not significantly different from those of animals in Group HC. 
Table 1. Weights of the epididymis and sex accessory gland complex of immature male little brown bats after restricted or ad-libitum feeding for 3 weeks

\begin{tabular}{|c|c|c|c|c|c|}
\hline \multirow[b]{2}{*}{ Group } & \multirow[b]{2}{*}{$\begin{array}{l}\text { No. of } \\
\text { bats }\end{array}$} & \multicolumn{3}{|c|}{ Epididymis wt (mg) } & \multirow{2}{*}{$\begin{array}{c}\text { Accessory } \\
\text { sex gland } \\
\text { complex wt (mg) }\end{array}$} \\
\hline & & Total & $\begin{array}{l}\text { Caput and } \\
\text { corpus }\end{array}$ & Cauda & \\
\hline FR (food restricted) & 9 & $2 \cdot 3 \pm 0 \cdot 2^{a}$ & $1 \cdot 6 \pm 0 \cdot 2^{\mathrm{b}}$ & $0 \cdot 6 \pm 0 \cdot 1^{\mathrm{a}}$ & $10 \cdot 1 \pm 0.9$ \\
\hline AL (ad-libitum fed) & 9 & $3.5 \pm 0.3^{b}$ & $2 \cdot 6 \pm 0 \cdot 3^{c}$ & $0 \cdot 9 \pm 0 \cdot 1^{\mathrm{a}}$ & $12 \cdot 6 \pm 0.9$ \\
\hline $\begin{array}{l}\text { HC (hibernating } \\
\text { controls) }\end{array}$ & 6 & $1 \cdot 6 \pm 0 \cdot 1^{a}$ & $0 \cdot 9 \pm 0 \cdot 1^{\mathrm{a}}$ & $0 \cdot 7 \pm 0.1^{\mathrm{a}}$ & $9.8 \pm 1.0$ \\
\hline F (one-way ANOVA) & & $\begin{array}{c}13.7 \\
P<0.001\end{array}$ & $\begin{array}{c}15.8 \\
P<0.001\end{array}$ & $\begin{array}{c}3.7 \\
P<0.05\end{array}$ & $P \stackrel{2.8}{>0.05}$ \\
\hline
\end{tabular}

Values are mean \pm s.e.m. Means with a superscript in common are not significantly different from one another; means with no superscripts in common are significantly different (Student-Newman-Keuls test).

\section{Discussion}

Plasma SBP concentrations have been shown to increase markedly around the time of birth in male primates (Anderson et al., 1976; Heyns, 1977), bats (Gustafson \& Damassa, 1984), rabbits (Berger et al., 1980) and hamsters (Gustafson et al., 1984). Amongst these mammals, the little brown bat is unusual in that it is not only a hibernating species but also one in which the pubertal process is interrupted and extended by the first winter hibernation period (Gustafson \& Damassa, 1984). If immature male bats are prematurely aroused during the second half of this first hibernation, resumption of the pubertal process can be examined in the laboratory. This resumption of the pubertal process is characterized by (1) elevations in plasma SBP concentrations which appear to be similar to those observed during the postnatal period, (2) increased total plasma testosterone concentrations, and (3) the activation of the spermatogenic process (Damassa et al., 1983; Damassa \& Gustafson, 1984; Gustafson \& Damassa, 1984).

Although the factors which control the postnatal as well as the post-arousal rise in plasma SBP levels in this species have not been determined, previous studies have shown that the post-arousal increases in this plasma protein do not depend on gonadal steroids, and furthermore are not influenced by changes in photoperiod during the second half of hibernation (Damassa \& Gustafson, 1984).

The increases in plasma SBP which occur in little brown bats during the postnatal and postarousal periods occur at times of rapid increases in body weight (Damassa et al., 1983; Gustafson \& Damassa, 1984). Additionally, studies in other mammals have indicated that food availability can have profound effects on reproductive functions (Delost, 1975; Howland, 1975; Millar \& Fairall, 1976; Berger, Negus, Sanders \& Gardner, 1981; Kenagy \& Bartholomew, 1981; Pirke \& Spyra, 1981 ; Eskes, 1983; Nelson, Dark \& Zucker, 1983; Barnes, 1984; for earlier references, see reviews by Leathem, 1970, 1975). Nevertheless, the results of the present study indicate that the induction of SBP in the little brown bat is independent of changes in food intake or body mass. Immature males that were fed a restricted diet, which prevented the post-arousal increases in body weight, still exhibited dramatic increases in plasma SBP which were indistinguishable from those of ad libitum-fed bats. Similarly, plasma SBP concentrations in adult male rabbits were not altered even by a chronic $50 \%$ reduction in food intake (Prasad, Nair, Sivakumar \& Rao, 1981). However, clinical studies have shown that plasma SBP titres are low in obese men and appear to be inversely related to the degree of obesity (Vermeulen, Verdonck, Van der Straeten \& Orie, 1969; DeMoor \& Joossens, 1970; Glass, Swerdloff, Bray, Dahms \& Atkinson, 1977; Amatruda, Harman, Pourmotabbed \& Lockwood, 1978; Kley, Solbach, McKinnan \& Kruskemper, 1979). Even though food restriction does not appear to influence SBPdevels, the precise relationship between $\odot: 14: 10 \mathrm{AM}$ 
circulating SBP and nutritional status under a variety of physiological and pathophysiological conditions remains to be determined.

In other studies it has been shown that elevated thyroid hormone levels are associated with increased SBP activity both in vivo (Yosha, Loncope \& Braverman, 1984; for reviews see Anderson, 1974; Heyns, 1977) and in vitro (Rosner, Aden \& Khan, 1984). Whether changes in circulating thyroid hormones in the little brown bat could be responsible for the postnatal or post-arousal increases in plasma SBP concentrations requires further investigation.

Although food restriction did not alter plasma SBP activity in little brown bats, it did significantly inhibit certain aspects of their pubertal reproductive development. Increases in testicular and epididymal (head/body) weights were significantly less in food-restricted males when compared to those in ad libitum-fed bats. Generally, undernutrition will delay sexual development in immature male mammals, decrease circulating testosterone concentrations and to a lesser extent inhibit spermatogenesis (e.g., Dickerson, Gresham \& McCance 1964; Mann, Rowson, Short \& Skinner, 1967; Leathem, 1970, 1975; Slob, Vreeburg \& Van Der Werff Ten Bosch, 1979; Lac \& Lac-Scanzi, 1984; Ryg, 1984). Although testicular weights in the present study were significantly lower in the food-restricted males, spermatogenesis was initiated in all animals. The inability of moderate food restriction to alter spermatogenesis in the little brown bat during this study may be due to the fact that this experiment focussed only on the first 3 weeks after arousal. Longer periods of food restriction and quantitative analysis of the gametogenic process, as described by Blank $\&$ Desjardins (1984), will be required to identify more precisely the effects of moderate food restriction on spermatogenesis in this species. Alternatively, spermatogenesis in little brown bats may be relatively insensitive to food restriction.

Arousal of immature male bats from hibernation resulted in a $20-30$-fold rise in circulating testosterone levels within 3 weeks. However, the accessory sex glands and apparently the tail of the epididymis remained unstimulated in food restricted and ad libitum-fed bats. Only the head/body region of the epididymis showed evidence of stimulation after arousal: weights of this region, unlike the tail, were significantly increased after arousal and this increase was partly inhibited by food restriction. This discrepancy of response between different regions of the bat epididymis appears to be similar to that in laboratory rodents in which the initial segments of the epididymis are apparently more dependent upon high levels of intraluminal testosterone than on plasma testosterone for stimulation and maintenance (Moniem, Glover \& Lubicz-Nawrocki, 1978; Fawcett \& Hoffer, 1979). The low level of peripheral androgen activity as indicated by the unstimulated state of the accessory glands and cauda epididymidis, in spite of the elevated plasma testosterone concentrations, suggests either that SBP may be exerting an inhibitory influence on peripheral androgen action, or that these tissues are relatively insensitive at this stage in their reproductive development to circulating androgens.

In conclusion, food availability does not appear to be an important factor in the regulation of circulating SBP titres in immature male little brown bats. However, moderate food restriction does inhibit aspects of the pubertal process in this species, apparently via a mechanism which does not involve alterations in plasma SBP activity.

This work was supported by the NIH (Grants HD16535 and HDOO485). We thank Grace Amico and Evie Gustafson for expert technical assistance. Antisera for the testosterone RIA was kindly provided by Dr B. V. Caldwell.

\section{References}

Amatruda, J.M., Harman, S.M., Pourmotabbed, G. \& Lockwood, D.H. (1978) Depressed plasma testosterone and fractional binding of testosterone in obese males. J. clin. Endocr. Metab. 47, 268-271.
Anderson, D.C. (1974) Sex-hormone-binding globulin. Clin. Endocr. 3, 69-96.

Anderson, D.C., Lasley, B.L., Fisher, R.A., Shepherd, J.H., Newman, L. \& Hendrickx, A.G. (1976) Trans- 
placental gradients of sex-hormone-binding globulin in human and simian pregnancy. Clin. Endocr. 5, $657-669$.

Bardin, C.W., Musto, N., Gunsalus, G., Kotite, N., Cheng, S.-L., Larrea, F. \& Becker, R. (1981) Extracellular androgen binding proteins. Ann. Rev. Physiol. 43, 189-198.

Barnes, B.M. (1984) Influence of energy stores on activation of reproductive function in male goldenmantled ground squirrels. J. comp. Physiol. B 154, 421-425.

Berger, M., Corre, M., Jean-Faucher, C., De Turckheim, M., Veyssiere, G. \& Jean, C. (1980) Age related changes in percent binding of testosterone and dihydrotestosterone and unbound testosterone and dihydrotestosterone in rabbit plasma. J. Steroid Biochem. 13, 423-429.

Berger, P.J., Negus, N.C., Sanders, E.H. \& Gardner, P.D. (1981) Chemical triggering of reproduction in Microtus montanus. Science, N.Y. 214, 69-70.

Blank, J.L. \& Desjardins, C. (1984) Spermatogenesis is modified by food intake in mice. Biol. Reprod. 30, $410-415$.

Damassa, D.A. \& Gustafson, A.W. (1984) Control of plasma sex steroid-binding protein (SBP) in the little brown bat: effects of photoperiod and orchiectomy on the induction SBP in immature males. Endocrino$\log y$ 115, 2355-2361.

Damassa, D.A., Gustafson, A.W. \& Chari, G.C. (1983) Control of plasma sex steroid-binding protein in the bat Myotis lucifugus lucifugus: induction of steroidbinding activity in immature males. J. Endocr. 97, $57-64$.

Delost, P. (1975) Un modèle de l'influence du facteur nutrition dans la reproduction des Mammifères: Le cycle sexuel saisonnier du Campagnol des champs. Bull. Soc. zool. Fr. 100, 41-66.

DeMoor, P. \& Joossens, J.V. (1970) An inverse relation between body weight and the activity of the steroid binding $\beta$-globulin in human plasma. Steroidologia $\mathbf{1}$, 129-136.

Dickerson, J.W.T., Gresham, G.A. \& McCance, R.A. (1964) The effect of undernutrition and rehabilitation on the development of the reproductive organs: pigs. J. Endocr. 29, 111-118.

Ekins, R.P. (1982) The role of binding proteins in hormone transport. In Immunoassays of Steroids in Saliva, pp. 64-86. Eds G. F. Read, D. Riad-Fahmy, R. F. Walker \& K. Griffiths. Alpha Omega Publishing Ltd, Cardiff.

Eskes, G.A. (1983) Gonadal responses to food restriction in intact and pinealectomized male golden hamsters. J. Reprod. Fert. 68, 85-90.

Fawcett, D.W. \& Hoffer, A.P. (1979) Failure of exogenous androgen to prevent regression of the initial segments of the rat epididymis after efferent duct ligation or orchidectomy. Biol. Reprod. 20, 162-181.

Glass, A.R., Swerdloff, R.S., Bray, G.A., Dahms, W.T. \& Atkinson, R.L. (1977) Low serum testosterone and sex-hormone-binding-globulin in massively obese men. J. clin. Endocr. Metab. 45, 1211-1219.

Gustafson, A.W. \& Damassa, D.A. (1984) Perinatal and postnatal patterns of plasma sex steroid-binding protein and testosterone in relation to puberty in the male little brown bat. Endocrinology 115, 2347-2354.
Gustafson, A.W. \& Damassa, D.A. (1985) Repetitive blood sampling from small peripheral veins in bats. J. Mammal. 66, 173-177.

Gustafson, A.W., Damassa, D.A. \& Kwiecinski, G.G. (1984) Plasma sex steroid-binding protein (SBP) in the little brown bat and Djungarian hamster: identification and temporal variations in males from birth through puberty. Biol. Reprod. 30 (Suppl. 1), 161, Abstr.

Heyns, W. (1977) The steroid-binding $\beta$-globulin of human plasma. Adv. Steroid Biochem. Pharmacol. 6, 59- 79 .

Howland, B.E. (1975) The influence of feed restriction and subsequent re-feeding on gonadotrophin secretion and serum testosterone levels in male rats. $J$. Reprod. Fert. 44, 429-436.

Kenagy, G.J. \& Bartholomew, G.A. (1981) Effects of day length, temperature, and green food on testicular development in a desert pocket mouse Perognathus formosus. Physiol. Zool. 54, 62-73.

Kley, H.K., Solbach, H.G., MeKinnan, J.C. \& Kruskemper, H.L. (1979) Testosterone decrease and oestrogen increase in male patients with obesity. Acta endocr., Copenh. 91, 553-563.

Lac, G. \& Lac-Scanzi, N. (1984) Etude de la spermatogènese chez le rat $W$ istar prépubère au cours d'une malnutrition protéino-energétique suivie d'une réalimentation équilibrée. Reprod. Nutr. Develop. 24, 487494.

Leathem, J.H. (1970) Nutrition. In The Testis, Vol. III, pp. 169-205. Eds A. D. Johnson, W. R. Gomes \& N. L. VanDemark. Academic Press, New York.

Leathem, J.H. (1975) Nutritional influences on testicular composition and function in mammals. In Handbook of Physiology, Sec. 7, Vol. V, pp. 225-232. Eds R. O. Greep \& D. W. Hamilton. Am. Physiol. Soc., Washington, D.C.

Mann, T., Rowson, L.E.A., Short, R.V. \& Skinner, J.D. (1967) The relationship between nutrition and androgenic activity in pubescent twin calves, and the effect of orchitis. J. Endocr. 38, 455-468.

Mickelson, K.E. \& Pétra, P.H. (1974) A filter assay for the sex steroid binding protein (SBP) of human serum. FEBS Lett. 44, 34-38.

Millar, R. \& Fairall, N. (1976) Hypothalamic, pituitary and gonadal hormone production in relation to nutrition in the male hyrax (Procavia capensis). $J$. Reprod. Fert. 47, 339-341.

Moniem, K.A., Glover, T.D. \& Lubicz-Nawrocki, C.W. (1978) Effects of duct ligation and orchidectomy on histochemical reactions in the hamster epididymis. $J$. Reprod. Fert. 54, 173-176.

Nelson, R.J., Dark, J. \& Zucker, I. (1983) Influence of photoperiod, nutrition and water availability on reproduction of male California voles (Microtus californicus), J. Reprod. Fert. 69, 473-477.

Pardridge, W.M. (1981) Transport of protein-bound hormones into tissues in vivo. Endocrine Rev. 2, 103123.

Pétra, P.H., Stanczyk, F.Z., Senear, D.F., Namkung, P.C., Novy, M.J., Ross, J.B.A., Turner, E. \& Brown, J.A. (1983) Current status of the molecular structure and function of the plasma sex steroidbinding protein (SBP). J. Steroid Biochem. 19, 699706. 
Pirke, K.M. \& Spyra, B. (1981) Influence of starvation on testosterone-luteinizing hormone feedback in the rat. Acta endocr., Copenh. 96, 413-421.

Prasad, K.V.S., Nair, K.M., Sivakumar, B. \& Rao, B.S.N. (1981) Effect of food restriction (undernutrition) on plasma sex hormone binding globulin (SHBG) capacity, liver drug metabolizing enzymes and uterine cytosol progesterone receptor levels in rabbits. Contraception 23, 563-576.

Rosner, W., Aden, D.P. \& Khan, M.S. (1984) Hormonal influences on the secretion of steroid-binding proteins by a human hepatoma-derived cell line. J. clin. Endocr. Metab. 59, 806-808.

Ryg, M. (1984) Effects of nutrition on seasonal changes in testosterone levels in young male reindeer (Rangifer tarandus tarandus). Comp. Biochem. Physiol. 77A, 619-621.
Siteri, P.K., Muraj, J.T., Hammond, G.L., Nisker, J.A., Raymoure, W.J. \& Kuhn, R.W. (1982) The serum transport of steroid hormones. Recent Prog. Horm. Res. 38, 457-510.

Slob, A.K., Vreeburg, J.T.M. \& Van Der Werfi Ten Bosch, J.J. (1979) Body growth, puberty and undernutrition in the male guinea-pig. Br. J. Nutr. 41, 231237.

Vermeulen, A., Verdonck, L., Van der Straeten, M. \& Orie, N. (1969) Capacity of the testosterone-binding globulin in human plasma and influence of specific binding of testosterone on its metabolic clearance rate. J. clin. Endocr. Metab. 29, 1470-1480.

Yosha, S., Longcope, C. \& Braverman, L.E. (1984) The effect of $\mathrm{D}$ - and $\mathrm{L}$-thyroxine on sex hormone-binding globulin in rabbits. Endocrinology 115, 1446-1450.

Received 13 December 1984 